\title{
An unusual mantle source region for nephelinites from the Oslo Rift, Norway
}

\author{
E. Y. ANTIIONY*, T. V. SEGALSTAD and E.-R. NEUMANN \\ Mineralogical-Geological Museum, University of Oslo, Sarsgt. 1, N-0562 Oslo 5, Norway
}

(Received June 28, 1988; accepted in revised form February 28, 1989)

\begin{abstract}
We have analyzed the trace-element and isotopic composition of a series of lavas and their constituent pyroxenes and calcite from near the town of Skien in the Permo-Carboniferous Oslo Rift. The series decreases in alkalinity upsection: the lowermost lavas are nephelinites, followed by basanites and finally alkali basalts. This sequence is accompanied by decreasing light rare earth element ( $L R E E$ ), $\mathrm{Th}, \mathrm{Nb}$ and $\mathrm{U}$ concentrations. Nd isotopic change is strongly correlated with the petrologic and chemical evolution. The nephelinites are characterized by $\epsilon_{\mathrm{Nd}}(300 \mathrm{Ma})$ of 1.0 to 1.6 , the basanites 1.9 to 2.2 and the alkali basalts 2.4 to $3.9 . \epsilon_{\mathrm{Sr}}(300 \mathrm{Ma})$ ranges from -10 to -15 and shows little change from one group to the next. Calcite segregations in the basaltic rocks show $\delta^{13} \mathrm{C}=-2.82 \%, \delta^{18} \mathrm{O}=7.7$ to $9.6 \%, \epsilon_{\mathrm{Sr}}=-6.5$ to -9.9 and $\epsilon_{\mathrm{Nd}}=0$ to +2 , values which are compatible with formation from magmatic $\mathrm{CO}_{2}$ exsolved from a mantle-derived silicate melt.

The $\mathrm{Sr}$ isotope values are unradiogenic relative to $\mathrm{Nd}$ for the nephelinites, causing these samples to fall to the lefthand side of most mantle-derived rocks on a $\epsilon_{\mathrm{Nd}} v s . \epsilon_{\mathrm{Sr}}$ diagram. They are similar to rocks from "high $\mu$ " (HIMU) sources and the recently proposed "LoNd array" (HART et al, 1986). The alkali basalts, with their higher $\epsilon_{\text {Nd }}$, lie close to the mantle array for $300 \mathrm{Ma}$ ago and resemble tholeitic magmatism in the Oslo Rift. We interpret these trends as representing evolution in which the earliest magmas were derived from a source with HIMU-LoNd characteristics, and successive magmas gradually acquired the more dominant mantle isotopic composition. Model age calculations permit either 1) that the nephelinite source was originally depleted then subsequently re-enriched in LREE or 2) that the nephelinite source was primitive with respect to $\mathrm{Nd}$ but had undergone $\mathrm{Rb}$ depletion. The nearby Fen carbonatite complex is about $250 \mathrm{Ma}$ older than Skien and its $\epsilon_{\mathrm{Nd}}$ is slightly more positive. A direct relationship between Fen and Skien would favor the first hypothesis.
\end{abstract}

\section{INTRODUCTION}

ABOUT TEN YEARS AGO JACOBSEN and WASSERBURG (1978) and JACOBSEN (1980) reported on the isotopic composition of rocks from the Oslo Rift, a continental rift of late Carboniferous and Permian age. Two samples from an alkaline mafic sequence near the town of Skien (Fig. 1) had approximately chrondritic $\epsilon_{\mathrm{Nd}}$ values $(+1.5)$ but quite negative $\epsilon_{\mathbf{S r}}$ values $(-13$ to -15$)$. The isotopic data were particularly interesting because of the tectonic and petrologic significance of the samples: the sequence at Skien constitutes the earliest and most alkaline of the mafic magmatism which accompanied the initiation of rifting in the Oslo Region (SEGALSTAD, 1978). Also, Skien is within a short distance of the Fen carbonatite complex, recently described by ANDERSEN (1987). Although there is a substantial difference in the ages of the two complexes, the lavas at Skien being approximately $300 \mathrm{Ma}$ old while the Fen carbonatite is $540 \mathrm{Ma}$ old, they have many petrologic and isotopic similarities.

Since Jacobsen's work, hundreds of $\mathrm{Nd}$ and $\mathrm{Sr}$ isotopic determinations have been made on mafic lavas. (For a compilation, see WORNER et al., 1986). However, those of Skien remain among the least radiogenic with respect to $\mathrm{Sr}$. Their closest analogues are found in other continental alkaline rocks (AliberT et al., 1986), carbonatites (BELL and BLENKINSOP, 1987) and oceanic basalts belonging to the HIMU (high $\mu$ ) group (ZINDLER and HART, 1986). As members of the HIMU group, they are coincident with the recently proposed LoNd array (HART et al., 1986). Given the importance of these isotopic signatures to understanding the nature and distri-

* Present address: Department of Geological Sciences, University of Texas at El Paso, El Paso, TX 79968, USA. bution of compositional heterogeneity in the mantle, we embarked on a detailed study of the isotopic composition of these rocks. The study contributes to characterization of heterogeneity in the mantle and the type of source regions tapped during the initiation of rifting.

\section{GEOLOGIC SETTING}

Igneous activity in the Oslo Rift commenced with volcanic eruptions approximately $300 \mathrm{Ma}$ ago. The lavas demonstrate a pattern of decreasing alkalinity and thickness from south to north (SEGALSTAD, 1978). The sequence at Skien in the southwestern edge of the exposed Rift (Fig. 1) was the earliest expression of volcanism and also the most alkaline: it is composed of nephelinites, basanites and alkali basalts. These were followed northwards by alkali basalts and then tholeiites. Basaltic volcanism in the rift was succeeded by more felsic volcanism, the rhomb porphyries (latites) and caldera-related rhyolites, and then by monzonite, syenite, peralkaline granite and biotite granite batholiths. The youngest of the plutonic rocks are approximately $250 \mathrm{Ma}$ old (SUNDVOLL, 1978). A more complete description of the geology of the Rift may be found in RAMBERG and LARSEN (1978) and NEUMANN and RAMBERG (1978).

\section{Major element composition}

The sequence at Skien consists of numerous thin flows, the total thickness of which is approximately 1500 meters. The sample numbers in the tables and figures are sequential with flow number 1 representing the bottommost flow. The approximate number of meters upsection for successive sample numbers is given in SEGALSTAD (1979). Flows numbered 63 and 66 are not stratigraphically correlated with the 


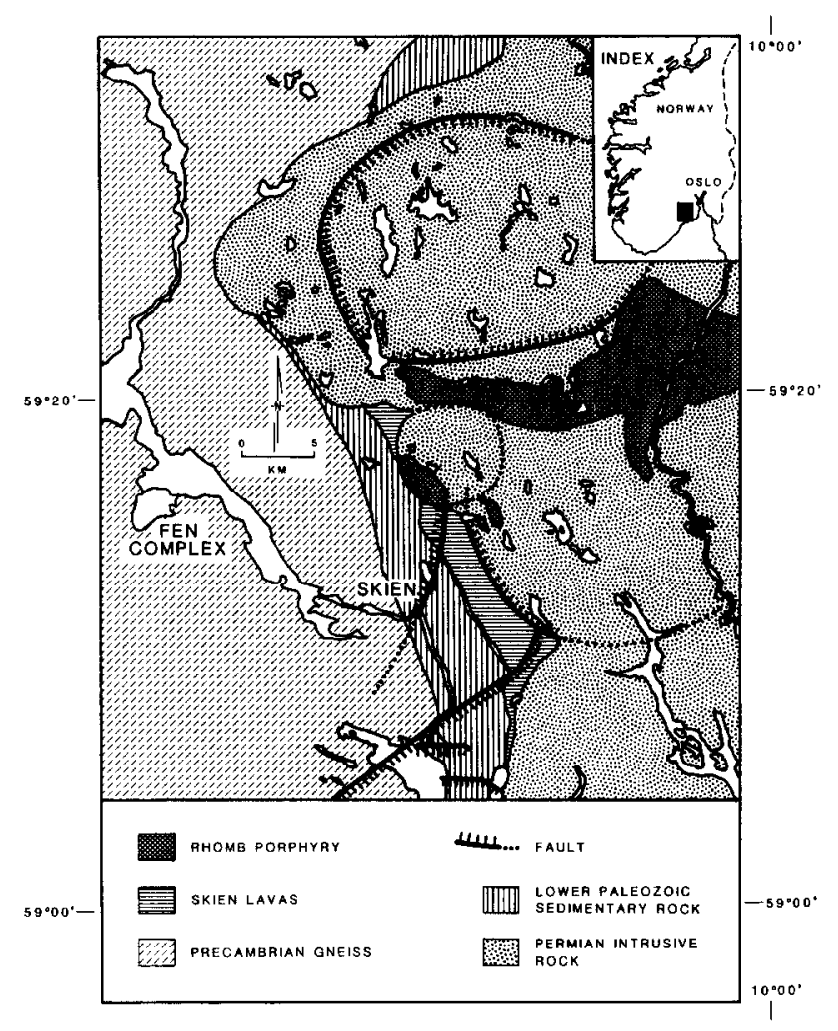

FIG. 1. Location map showing the location and distribution of rock types at Skien (after SEGALSTAD, 1975). rest of the section because they lie across a fault. They are included in the groups below on the basis of their chemical composition; their isotopic systematics are similar to the sequence proper but not identical. Major element compositions reported in Table 1 are from SEGALSTAD (1979). They were analyzed by XRF for all elements except Na (INAA) and $\mathrm{FeO}$ (wet chemical analysis). They have not been recalculated on a volatile-free basis. Catanorms are reported as a matter of Norwegian tradition since they were invented by T. F. W. Barth; negative quartz in samples 10 and 36 are attributed to minerals, such as melanite, which consume $\mathrm{Ca}$ and leave a deficiency with respect to $\mathrm{Si}$ in the calculation (SEGALSTAD, 1979).

All of the flows are ultramafic to mafic and alkaline. According to IUGS recommendations (LE BAS et al., 1986, LE BAS, pers. commun.), they are classified as on a chemical or normative basis as nephelinites, basanites, and alkali basalts. Nephelinites and basanites are distinguished from alkali basalts on the basis of their total alkalies and silica content: the former have $\mathrm{SiO}_{2}$ less than $45 \mathrm{wt} \%$, while the latter have $\mathrm{SiO}_{2}$ greater than $45 \mathrm{wt} \%$ and total alkalies less than $5 \mathrm{wt} \%$. Basanites and nephelinites are subdivided on the basis of their normative albite: both contain greater than 5\% normative nepheline, while nephelinites have less than $5 \%$ normative albite and basanites have greater than 5\%.

There is a quite marked progression towards less strongly undersaturated and less alkalic rocks upsection within the sequence (Table 1). According to the criteria stated above, the lowermost flows (samples 1, 5, 10 and also 36) are neph-

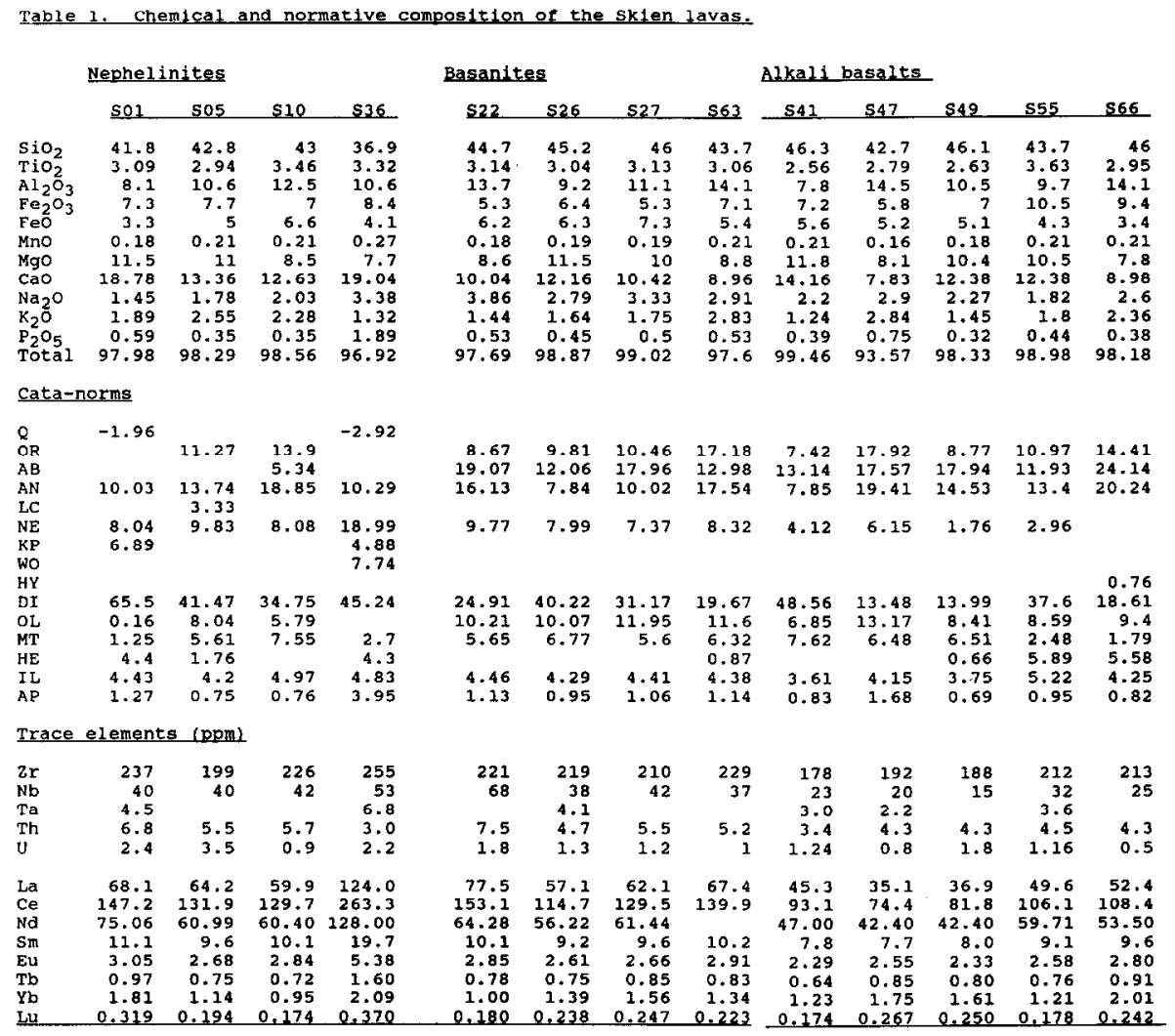


elinites: they are characterized by high values for normative nepheline (8-10\%) and low values of normative albite (0$\sim 5 \%$, to include sample 10 with a marginal ab content of 5.34 ). They were followed by basanite flows (samples 22 , 26,27 ) with similar values of normative nepheline (7-10\%) and higher values of normative albite (12-19\%). Flow number 63 has affinities with this group. The basanites were succeeded by alkali basalts, which contain substantially lower normative nepheline (2-6\%). Flow number 66 belongs to this group.

\section{Petrography}

Detailed descriptions of the petrography and nomenclature of the rocks may be found in SEGaLSTAD (1976, 1979). We emphasize that the classification discussed above is based on normative not modal mineral composition. The following generalizations concerning mineral content may be made: clinopyroxene is found as a phenocryst in flows throughout the sequence. It is strongly zoned and characterized by rounded or sub-rounded cores of chrome-rich diopside and euhedral rims of titaniferous salite. Samples with tuffaceous textures usually exhibit less well-developed rims than do flows.

In the lavas classified as nephelinites, olivine and pseudomorphs after olivine are found. These demonstrate conspicuous reaction rims of serpentine, magnetite and clinopyroxene. In the nephelinites and basanites, groundmass phases include melanite, apatite, magnetite and nepheline. Nepheline does not occur as a phenocryst, and the modal percentage of nepheline in the nephelinites and basanites has not been quantified.

In the flows classified as alkali basalts, nepheline has not been found as a groundmass phase. Plagioclase, however, does occur as both a phenocryst and as groundmass phase.

Some of the nephelinites contain calcite as both amygdule fillings and millimeter-size spherical segregations in the groundmass. Given the alkaline nature of the flows, SEGALSTAD (1976) suggested that the calcite formed from carbon dioxide exsolved from the magma. The $\mathrm{C}, \mathrm{O}, \mathrm{Sr}$ and $\mathrm{Nd}$ isotopic compositions of the calcite, reported herein, have a dominantly mantle signature and thus support the contention. Other examples of proposed magmatic calcite may be found in LUCIDO et al. (1980) and EXLEY and JONES (1983).

\section{ANALYTICAL PROCEDURES}

Rock powders used for major-element analysis by Segalstad were analyzed for trace-element and isotopic compositions. In addition, cores and rims of clinopyroxene phenocrysts were separated by handpicking, which was facilitated by the color difference between pale green diopside cores and brown salite rims, and analyzed for their $\mathrm{Sr}$ and $\mathrm{Nd}$ isotopic composition. $\mathrm{Sr}, \mathrm{Nd}, \mathrm{C}$ and $\mathrm{O}$ isotopic compositions were determined for calcite segregations.

\section{Trace-element analysis}

Rare-earth elements (REE) were analyzed using RNAA techniques (BRUNFELT et al., 1974), and $\mathrm{Zr}$, Th and $\mathrm{Nb}$ by XRF. Th and $\mathrm{U}$ were determined by natural gamma-ray radiation on $1 \mathrm{~kg}$ crushed samples using a $\mathrm{Ge}(\mathrm{Li})$ detector. All analyses were done by us at the Mineralogical-Geological Museum and the Department of Geology, University of Oslo, and the Institute for Energy Technology, Kjeller.

\section{Sr and Nd isotopic analyses}

Analyses were performed by us at the Mineralogical-Geological Museum of the University of Oslo. The clinopyroxene separates were washed for one hour in warm $1 \mathrm{~N} \mathrm{HCl}$. They did not, however, undergo vigorous acid washing (see, for example, ZINDLER and $\mathrm{J}_{\mathrm{A}}$ GOUTZ, 1988). Dissolution and chemical separation proceeded as for rock powders.

Powders were digested in $\mathrm{HF}$ in an oven at $80^{\circ} \mathrm{C}$ for five days, and aliquots were spiked with a mixed ${ }^{87} \mathrm{Rb}-{ }^{84} \mathrm{Sr}$ and ${ }^{149} \mathrm{Sm}-{ }^{148} \mathrm{Nd}$ spike. Aliquots of $\mathrm{Rb}, \mathrm{Sr}$ and the REE were separated on cation exchange columns, and Sm and $\mathrm{Nd}$ on diethyl hexyl hydrogen phosphate on teflon beads. Laboratory blanks for this period were less than 1 nanogram for both $\mathrm{Sr}$ and $\mathrm{Nd}$.

Isotopic ratios were measured on a VG 354 mass spectrometer which has full automation and five collector capacity. Results obtained for BCR-1, which was processed simultaneously with the rock powders, are reported in Table 2, along with values used for calculating epsilon values and model ages. $\mathrm{Pb}$ isotopes (Table 2 ) were analyzed at the University of California, Santa Barbara (NEumanN et al., 1988).

\section{Calcite segregations}

Samples containing calcite were crushed into 2 to $3 \mathrm{~mm}$ diameter pieces and the calcite hand-picked. The calcite was then powdered in an agate mortar and splits taken for the stable and radiogenic isotopic analyses.

Powders for $\mathrm{Sr}$ and $\mathrm{Nd}$ analysis were dissolved in $0.5 \mathrm{~m}$ nitric acid for ten minutes, centrifuged, and then evaporated. This procedure was adopted so as to minimize the dissolution of (and thus contamination by) non-calcite material. After evaporation, the residue was weighed, and this weight was used in spike calculations. Except for this initial treatment, chemical separation and analysis was identical to that for solutions of silicate powders.

The powders for carbon and oxygen isotopic analysis were dissolved with $100 \%$ phosphoric acid in a vacuum line at $25^{\circ} \mathrm{C}$. Analyses were performed on a Finnegan MAT 251 mass spectrometer with triple collector capacity. Values obtained for standard materials are reported in Table 3.

\section{ANALYTICAL RESULTS}

The flows from the lower part of the section, the nephelinites and basanites, have steeper REE patterns and higher contents of the light rare earth elements than the alkali basalts from the upper part of the section (Fig. 2). The distinction between lower and upper flow is found in elements other than the REE. Figure 3 illustrates abundances of elements relative to mid-ocean ridge basalts (MORB). It shows that the lower flows are enriched in $\mathrm{Th}$ and $\mathrm{Nb}$ relative to the upper flows. The same is probably true of $\mathrm{U}$ and $\mathrm{Ta}$ (Table 1), although the differences are obscured by analytical uncertainty. $\mathrm{Zr}$ and $\mathrm{Ti}$ are not as enriched in the Skien samples relative to MORB, nor do these elements serve as good discriminants between the flow types. The high $U$ contents result in $\mathrm{Nb} / \mathrm{U}$ ratios which are smaller than those found in the vast majority of oceanic basalts (HoFMANN et al., 1986). $\mathrm{Nb} / \mathrm{U}$ for the samples from Skien range from approximately 10 to 40 , while the average for both MORB and ocean-island basalts (OIB) is $47 \pm 10$.

The heavy rare-earth elements (HREE) are depleted in all samples from Skien relative to MORB; that is, for example, the ratios of elemental concentrations for $\mathrm{Yb}$ and $\mathrm{Lu}$ are less than 1 (Fig. 3). This depletion would be caused by a mineral residual during melting which had partition coefficients for the HREE greater than 1. Garnet is a mineral with these 


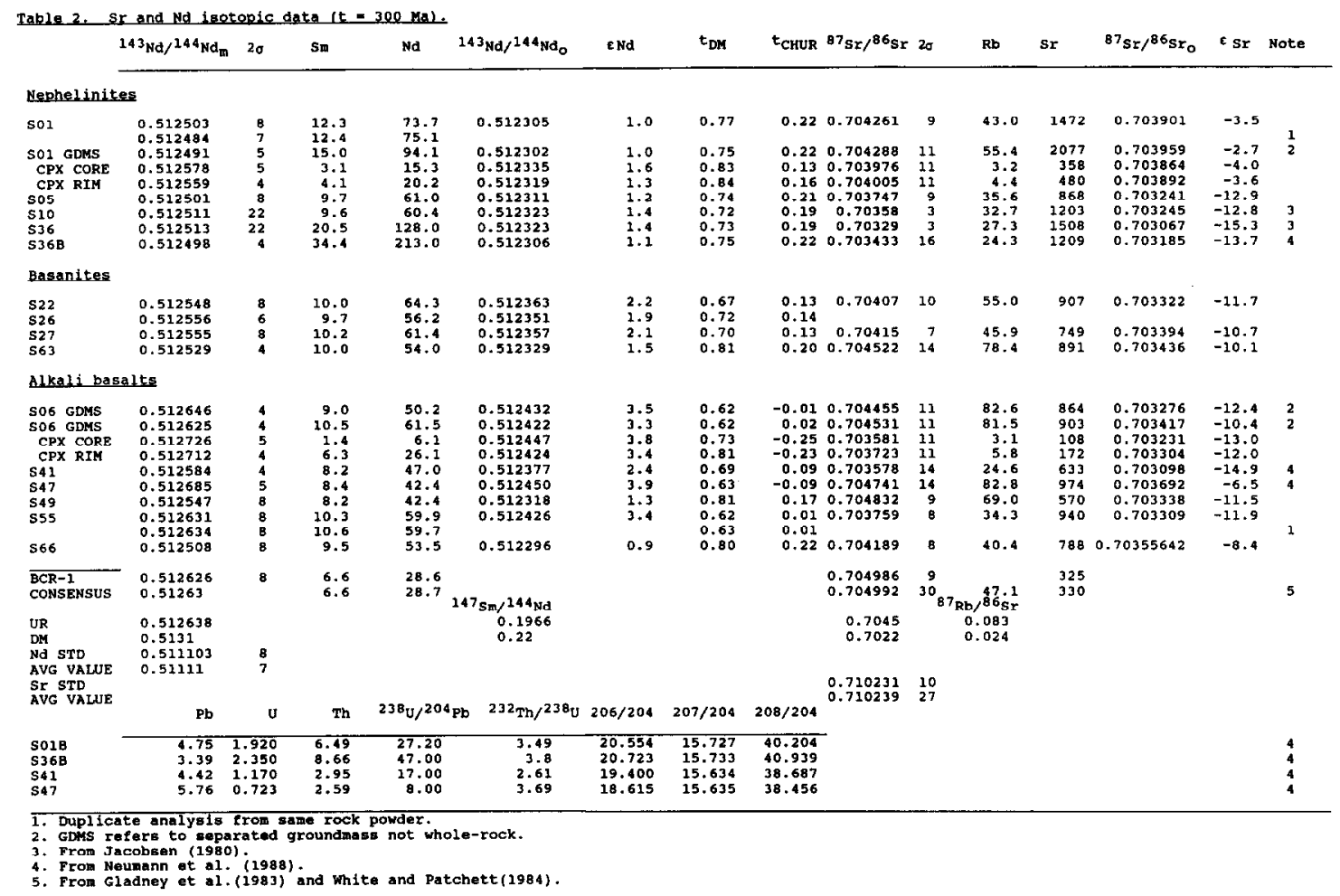

characteristics, and, thus, HREE depletion relative to MORB has been interpreted as reflecting the generation of magmas from a garnet-bearing source. This would imply a minimum depth of generation of approximately $60 \mathrm{~km}$. This estimate of depth is consistent with, though not as stringent as, that provided from experimental studies which suggest a depth of approximately 100 to $125 \mathrm{~km}$ for the generation of nephelinitic magmas (GREEN, 1970; SEGALSTAD, 1979).

\section{Isotopic composition of the whole rock}

The isotopic composition for whole-rock samples is given in Table 2 and plotted in Figs. 4 and 5. Figure 4 shows $\epsilon_{\mathrm{Nd}}$ plotted against $\mathrm{Sm} / \mathrm{Nd}$. The parameter $\mathrm{Sm} / \mathrm{Nd}$, like $\mathrm{La} / \mathrm{Yb}$, indicates the degree of LREE enrichment of the samples. It is used here because we have high-precision isotope dilution determinations corresponding to each isotopic analysis. Petrologic designations based on the major-element chemistry carry through to the isotopic composition: the nephelinites have $\epsilon_{\mathrm{Nd}}$ values of 1.0 to 1.4 , and the basanites have values of 1.9 to 2.2. Sample 63 has values which are similar to those for the basanites within the sequence proper. $\epsilon_{\mathrm{Nd}}$ values for the alkali basalts encompass the entire range observed; however, they are predominantly more positive than those for nephelinites and basanites. In fact, excluding sample 66 which, as was described in the section on major-element

Table 3. Isotopic composition of calcite $(t=300 \mathrm{Ma}$.)

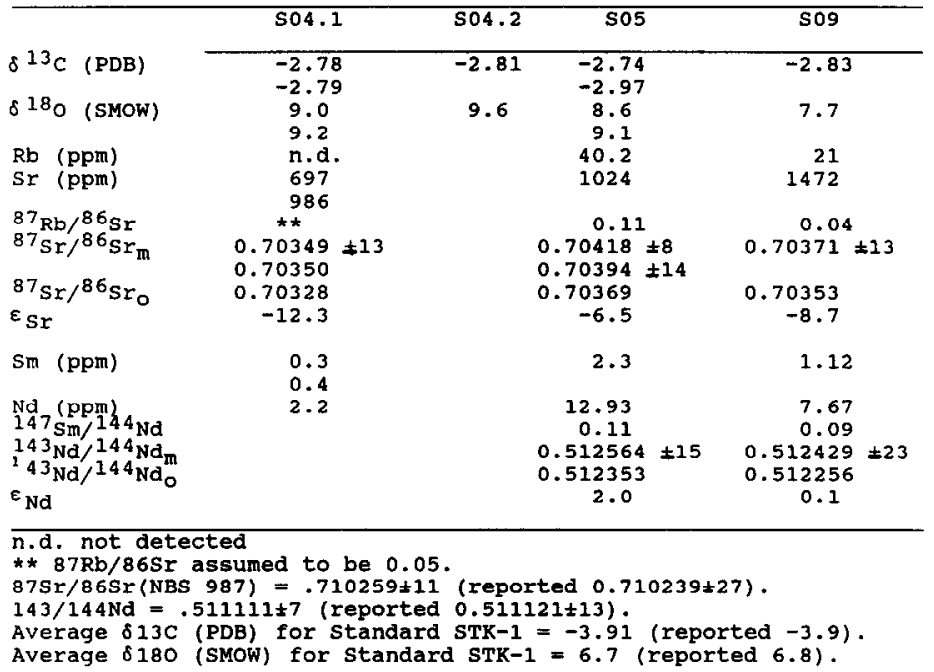




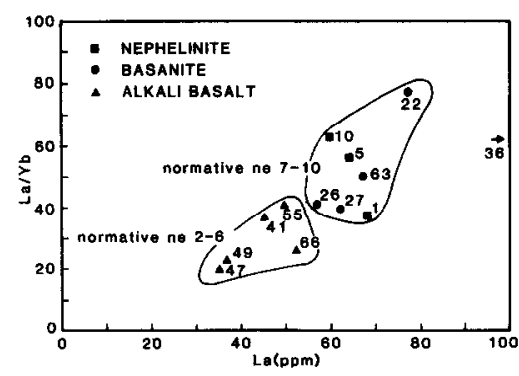

FiG. 2. La/Yb versus La from whole-rock analyses of the Skien lavas. The highly alkaline lower flows, characterized by larger amounts of normative nepheline, have greater degrees of LREE enrichment than do the alkali basalts which constitute the upper part of the section. Sample numbers correspond to analyses in Table 1 .

chemistry, is not in the sequence proper, sample 49 is the sole aberrant value. There are no apparent differences in its petrography or chemical composition which would explain its low $\epsilon_{\mathrm{Nd}} v i s$ - $a$-vis the other alkali basalts in the upper part of the sequence.

$\epsilon_{\mathrm{Sr}}(300 \mathrm{Ma})$ varies from -2.7 to -15.3 . We use the $\epsilon_{\mathrm{Sr}}$ nomenclature despite uncertainties in the estimate of the isotopic composition of the undepleted mantle reservoir because it simplifies comparison of the reservoirs for Skien magmas with those for basaltic rocks of other ages. The range in $\epsilon_{\mathbf{S r}}$ is much more restricted $(-10.1$ to -15.3$)$ if samples 1,47 and 66 are excluded. Reasons to suspect resetting of the $\mathrm{Sr}$ isotopic composition of 1 and 47 are discussed below. $\epsilon_{\mathrm{Sr}}$ values are low relative to $\epsilon_{\mathrm{Nd}}$ (Fig. 5), a characteristic first noted by JACOBSEN and WASSERBURG (1978). The values fall on the unradiogenic Sr side of the "mantle array" and are similar, in terms of $\mathrm{Sr}$ and $\mathrm{Nd}$, to samples belonging to the HIMU group.

The HIMU group constitutes an end-member of the "LoNd array" proposed by HART et al. (1986), and the samples from Skien lie on this array in $\mathrm{Nd}-\mathrm{Sr}$ space. These are among the first continental volcanic rocks and also the first non-modern flows identified with the array.

We have fewer data for the $\mathrm{Pb}$ isotopes from the lavas of Skien; however, affinities to the HIMU and LoNd groups

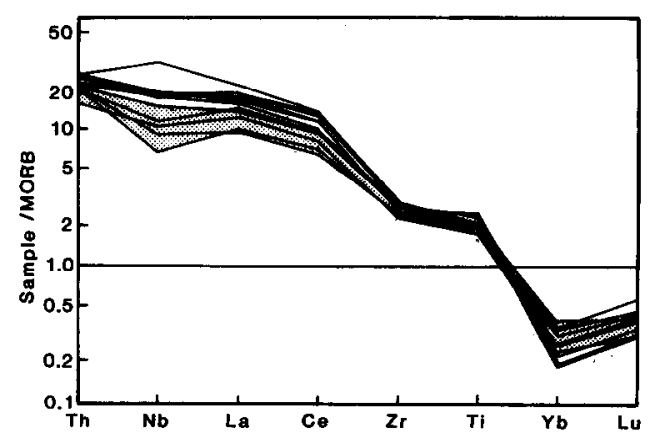

FIG. 3. Logarithmic plot of elemental concentration in the sample versus mid-ocean ridge basalts for the Skien lavas. Shaded portion represents the alkali basalt samples; unshaded lines represent nephelinites and basanites. Note that $\mathrm{Th}$ and $\mathrm{Nb}$ as well as the LREE are enriched in the latter, while $\mathrm{Zr}$, Ti and the HREE are similar for all lavas.

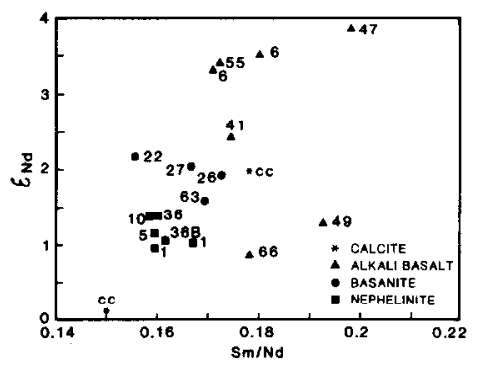

Fig. 4. Epsilon Nd versus $\mathrm{Sm} / \mathrm{Nd}$ for lavas and calcite ( $\mathrm{cc}$ ) from Skien. Nephelinites squares, basanites filled circles, and alkali basalts triangles. Note that, with the exception of samples 49 and 66 , decreasing LREE enrichment is correlated to increasing $\epsilon_{\mathrm{Nd}}$.

appear to extend to these isotopes as well (Fig. 6). All samples have radiogenic $\mathrm{Pb}$ isotopic compositions and plot along the $\mathrm{Pb}-\mathrm{Pb}$ arrays (both 208/204 vs. 206/204 and 207/204 vs. 206/204) for MORB and ocean-island basalts (ZINDLER and HART, 1986). The nephelinites (S01 and S36B) have the most radiogenic values and lie close to St. Helena and the HIMU end-member of these arrays. Further, the high $\mathrm{Pb}$ radiogenic values for the nephelinites correlate with the least radiogenic $\mathrm{Sr}$ values, in accordance with the negative correlation between ${ }^{87} \mathrm{Sr} /{ }^{86} \mathrm{Sr}$ and ${ }^{206} \mathrm{~Pb} /{ }^{204} \mathrm{~Pb}$ for the LoNd array (HART et al., 1986).

\section{Chemical and isotopic composition of clinopyroxene}

The clinopyroxenes are strongly zoned from a magnesiumrich, rounded core to a titanium-rich rim (Table 4). The chrome-rich magnesian cores and the strong zoning between core and rim imply that the cores were either crystallized from or incorporated into the magma before its final ascent. Pyroxenes with similar chemical composition and history have been described by AOKI and KUSHIRO (1968), WASS (1979) and MASON (1985). Substitutional mechanisms in the pyroxenes include both titanopyroxene $\left(\mathrm{MgSi}_{2}=\mathrm{TiAl}_{2}\right)$ and $\mathrm{Ca}$-Tschermaks $\left(\mathrm{MgSi}=\mathrm{Al}^{\text {vi }} \mathrm{Al}^{\mathrm{iv}}\right)$. Titanium and tetrahedral $\mathrm{Al}$ show a strong positive correlation $(\mathrm{r}=0.91$ for

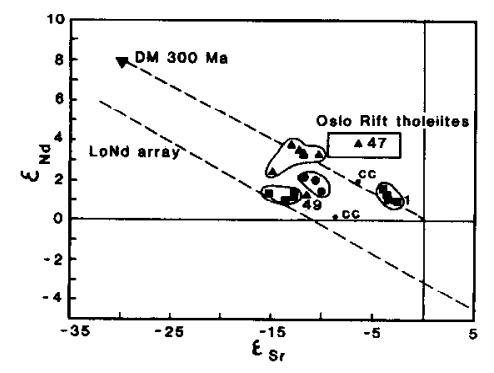

FIG. 5. $\epsilon_{\mathrm{Nd}}$ versus $\epsilon_{\mathrm{Sr}}$ for lavas, clinopyroxenes and calcite from Skien. Fields delineate nephelinites (squares), basanites (filled circles), and alkali basalts (triangles). Whole-rock and clinopyroxene analyses of sample 1 (filled squares) and sample 47 fall outside the fields for most samples and are discussed in the text. DM refers to the isotopic composition of depleted mantle at $300 \mathrm{Ma}$ ago using constants from Table 2. LoNd array defined by HART et al. (1986). The box labeled Oslo Rift tholeiites represents typical values of the tholeiites which followed Skien alkaline magmatism (NEUMANN et al., 1988). 


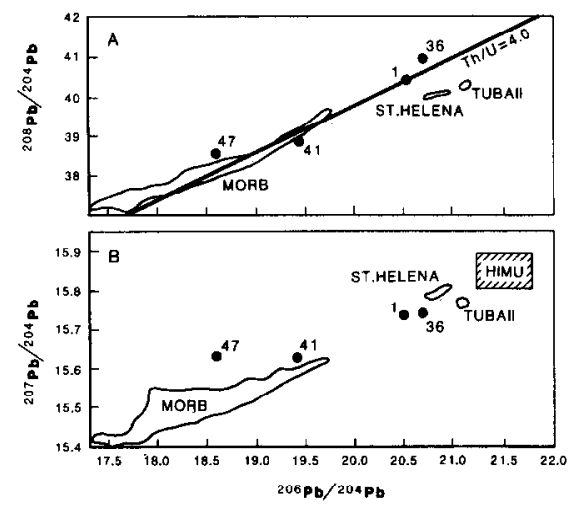

FIG. 6. $\mathrm{Pb}$ isotope diagrams for oceanic basalts (modified from ZINDLER and HART, 1986). Sample designations for lavas from Skien are from Table 2.

$\mathrm{n}=54$ ), which suggests that the dominant mechanism of titanium substitution in the rims was via the titanopyroxene molecule, a substitution favored by low pressure. The rims probably represent crystallization under approximately atmospheric pressure, an interpretation strengthened by the observation that they are poorly developed in the flows which show explosive, tuffaceous textures.

$\mathrm{Sr}$ and $\mathrm{Nd}$ isotopic compositions for clinopyroxene separates from two flows are listed in Table 2. Core, rim and matrix are close to isotopic equilibrium, although in both examples the rim is more like the matrix than is the core. Further, with the exception of the Sr value for sample 1, which will be discussed below, the isotopic composition of the pyroxene core and rim are similar to values for other flows within the same chemical group.

\section{Isotopic composition of the calcite segregations}

$\mathrm{Sr}, \mathrm{Nd}, \mathrm{O}$ and $\mathrm{C}$ isotopic compositions for calcite from three separate nephelinites (samples 4,5 and 9) are reported in Table 3. The values for S04.1 correspond to large, amyg- daloidal segregations and S04.2 to finely-dispersed, globular calcite of approximately $1 \mathrm{~mm}$ diameter in the matrix. These textures suggest that exsolution of $\mathrm{CO}_{2}$ occurred during solidification of the magma, that is, after extrusion of the lava and at low pressure and high temperature.

$\delta^{13} \mathrm{C}$ values are quite similar for all analyses, the average being $-2.82 \% o(1 \sigma=0.03 \%)$. This value is higher than the average mantle value of -5 to $-6 \%$, which is based on a synthesis of diamond and carbonatite studies (DEINES et al., 1987). There are, however, examples of $\delta^{13} \mathrm{C}$ of $-3 \%$ from carbonatites near Lake Victoria, Malawi, and Chilwa in Africa and St. Andre in Canada (DEINES and Gold, 1973). The African examples occur along a north-south trending belt in the inter-rift area between the Eastern and Western Rifts. Gases interpreted to be from a primitive source in the Hawaiian islands also have values of -3.6 to $-3.0 \%$ (GERLACH and THOMAS, 1986). Recent work has suggested that a positive correlation may exist between ${ }^{3} \mathrm{He} /{ }^{4} \mathrm{He}$ and $\delta{ }^{13} \mathrm{C}$, with the heavier carbon isotopic composition being typical of primordial sources (HoNDA et al., 1987). $\epsilon_{\mathrm{Nd}}$ of the calcite is 0 to +2 , similar to that for the silicate portion of the rock (Fig. 4). Thus, if we accept the hypothesis that the $C$ values reflect a heavy carbon reservoir, both $\mathrm{C}$ and $\mathrm{Nd}$ isotopic values are compatible with derivation of those components from a primitive rather than a depleted (e.g. asthenospheric) source.

Alternatively, if carbon isotopes represent simple exsolution from a parental magma, rather than a re-equilibrated magma such as modeled by GERLACH and THOMAS (1986), $\delta^{13} \mathrm{C}$ may reflect the average mantle value of -5 to $-6 \%$. The temperature of the nephelinite magma at the time of extrusion would be approximately $1300^{\circ} \mathrm{C}$ (SCHAIRER and YODER, 1960; SEGALSTAD, 1979). $\delta^{13} \mathrm{C}$ fractionation between $\mathrm{CO}_{2}$ vapor and theoliitic magma is $4.3 \%$ at 1120 to $1280^{\circ} \mathrm{C}$ and 7 to $8.5 \mathrm{~kb}$ (JAVOY et al., 1978). GERLACH and THOMAS (1986) calculate a similar value (3.8\% ) from the data of DES MARAIS and MOORE (1984). Because fractionation decreases with increasing temperature (to perhaps $-3 \%$ at $1300^{\circ} \mathrm{C}$ ), the calcite segregations could have exsolved from a parental magma with values between -6 and $-7 \%$.

Table 4. clinopyroxene analyses.

\begin{tabular}{|c|c|c|c|c|c|c|c|c|}
\hline & \multicolumn{2}{|c|}{ S11 } & \multicolumn{2}{|c|}{$\begin{array}{l}\text { S11 } \\
-\end{array}$} & \multicolumn{2}{|c|}{$\begin{array}{l}\text { S25 } \\
---\end{array}$} & \multicolumn{2}{|c|}{$\$ 25$} \\
\hline & CORE & RIM & CORE & RIM & CORE & RIM & CORE & RIM \\
\hline $\begin{array}{l}\mathrm{SiO} 2 \\
\mathrm{TiO} 2 \\
\mathrm{~A} 12 \mathrm{O} 3 \\
\mathrm{Fe} 2 \mathrm{O} 3 \text { * } \\
\mathrm{FeO} \\
\mathrm{MgO} \\
\mathrm{CaO} \\
\mathrm{Na2O}\end{array}$ & $\begin{array}{r}52.87 \\
0.71 \\
2.20 \\
1.44 \\
2.52 \\
16.93 \\
22.40 \\
0.46\end{array}$ & $\begin{array}{r}47.43 \\
2.90 \\
7.10 \\
2.99 \\
4.42 \\
13.12 \\
22.52 \\
0.51\end{array}$ & $\begin{array}{r}49.65 \\
1.67 \\
5.64 \\
2.92 \\
3.22 \\
14.79 \\
22.18 \\
0.56\end{array}$ & $\begin{array}{r}47.33 \\
2.69 \\
5.52 \\
3.67 \\
4.18 \\
13.06 \\
22.66 \\
0.47\end{array}$ & $\begin{array}{r}52.33 \\
0.46 \\
2.19 \\
2.17 \\
2.28 \\
16.99 \\
22.37 \\
0.38\end{array}$ & $\begin{array}{r}45.09 \\
3.67 \\
6.74 \\
4.44 \\
3.71 \\
12.36 \\
22.83 \\
0.48\end{array}$ & $\begin{array}{r}51.50 \\
0.93 \\
2.88 \\
2.41 \\
2.37 \\
16.14 \\
22.45 \\
0.44\end{array}$ & $\begin{array}{r}46.03 \\
2.59 \\
5.50 \\
4.97 \\
2.63 \\
12.84 \\
22.93 \\
0.46\end{array}$ \\
\hline & 99.53 & 100.99 & 100.63 & 99.58 & 99.17 & 99.32 & 99.12 & 97.95 \\
\hline $\begin{array}{l}\text { IV } \\
--\end{array}$ & & & & & & & & \\
\hline $\begin{array}{l}\text { Si } \\
\text { AI }\end{array}$ & $\begin{array}{l}1.933 \\
0.067\end{array}$ & $\begin{array}{l}1.746 \\
0.254\end{array}$ & $\begin{array}{l}1.815 \\
0.185\end{array}$ & $\begin{array}{l}1.771 \\
0.229\end{array}$ & $\begin{array}{l}1.923 \\
0.077\end{array}$ & $\begin{array}{l}1.701 \\
0.299\end{array}$ & $\begin{array}{l}1.899 \\
0.101\end{array}$ & $\begin{array}{l}1.752 \\
0.248\end{array}$ \\
\hline VI & & & & & & & & \\
\hline $\begin{array}{l}\mathrm{Al} \\
\mathrm{Ti} \\
\mathrm{Fe} 3+ \\
\mathrm{Fe} 2+ \\
\mathrm{Mg} \\
\mathrm{Ca} \\
\mathrm{Na}\end{array}$ & $\begin{array}{l}0.028 \\
0.020 \\
0.040 \\
0.077 \\
0.923 \\
0.877 \\
0.033\end{array}$ & $\begin{array}{l}0.054 \\
0.080 \\
0.083 \\
0.136 \\
0.720 \\
0.888 \\
0.036\end{array}$ & $\begin{array}{l}0.058 \\
0.046 \\
0.080 \\
0.098 \\
0.806 \\
0.869 \\
0.040\end{array}$ & $\begin{array}{l}0.015 \\
0.076 \\
0.103 \\
0.131 \\
0.729 \\
0.909 \\
0.034\end{array}$ & $\begin{array}{l}0.018 \\
0.013 \\
0.060 \\
0.070 \\
0.931 \\
0.881 \\
0.027\end{array}$ & $\begin{array}{l}0.000 \\
0.104 \\
0.126 \\
0.117 \\
0.695 \\
0.923 \\
0.035\end{array}$ & $\begin{array}{l}0.024 \\
0.026 \\
0.067 \\
0.073 \\
0.887 \\
0.887 \\
0.031\end{array}$ & $\begin{array}{l}0.000 \\
0.074 \\
0.142 \\
0.084 \\
0.729 \\
0.935 \\
0.034\end{array}$ \\
\hline
\end{tabular}


$\epsilon_{\mathrm{S} \Gamma}$ ranges from -6.5 to -9.9 , which, although not as negative as the -10 to -15 observed in the coexisting silicate phases, is still quite non-radiogenic.

$\delta^{18} \mathrm{O}$ varies from 7.7 to $9.6 \%$ relative to SMOW; these values tend to be higher than the 5.4 to $6.3 \%$ thought to characterize the mantle (SHEPHARD, 1982). However, extrapolation of the fractionation factor for $\mathrm{CO}_{2}$ vapor and diopside (BoTTINGA, 1968; BotTINGA and JAVOY, 1974; KIEFFER, 1982; MATTHEws et al., 1983) to temperatures representative of nephelinite magma yields a value of 3 to $4 \%$ (and fractionation between $\mathrm{CO}_{2}$ and calcite is about zero at $1300^{\circ} \mathrm{C}$ ). Thus, the silicate magma from which the $\mathrm{CO}_{2}$ exsolved may have been similar to typical mantle values.

The isotopic data are not consistent with the carbonate having been derived from local sedimentary reservoirs. Limestones from the Oslo Region have $\delta^{13} \mathrm{C}$ of -10 to $+3 \%$ and shales -29 to $-22 \%$ (SEGALSTAD et al, 1986). Remobilization of this sedimentary carbon, either by magmatic or hydrothermal processes, would have resulted in lower $\delta^{13} \mathrm{C}$ values and with much greater variability than observed in the calcite segregations. $\delta^{18} \mathrm{O}$ from sedimentary sources could resemble magmatic values if there had been high-temperature equilibration; however, hydrothermal transport of aqueous bicarbonate would have resulted in much lower $\delta^{18} \mathrm{O}$ values. Also, the $\mathrm{Sr}$ isotope ratios would have been much higher if Proterozoic or Paleozoic reservoirs had been involved to any great extent.

Given the magmatic nature of the calcite, it is interesting that the abundance of the REE in the calcite is lower than in the coexisting whole-rock silicate (Table 3 ). To the extent that the whole-rock values reflect magma composition at the time of exsolution, the low values imply a partition coefficient for carbonate fluid versus silicate melt of less than one, the opposite of what has been reported from experimental studies (WENDLANDT and HARRISON, 1979). There is some evidence that at very low (approximately atmospheric) pressure the REE prefer melt to carbonate vapor (BEDSON, 1984). Given our previous interpretation of the timing of carbonate exsolution, the low abundance of the REE may be interpretable in light of Bedson's experimental data.

\section{DISCUSSION}

The Sr and Nd isotopic data indicate a temporal evolution from early nephelinites having approximately chrondritic $\epsilon_{\mathrm{Nd}}$ values and non-radiogenic $\epsilon_{\mathrm{Sr}}$ to later alkali basalts characterized by more typical mantle values. We interpret the coupled chemical and isotopic changes to reflect participation of at lcast two different reservoirs during magma genesis. In addition to the primary trend, a few samples appear to have undergone a secondary process, and we examine this secondary process before turning to the principal one.

\section{Contamination}

Values of $\mathrm{Sr} / \mathrm{Nd}$ and $\epsilon_{\mathrm{Sr}}$ for most samples are quite similar, with only a few falling outside the field defined by the others (Fig. 7). There are various reasons for exclusion from the field. The low $\mathrm{Sr} / \mathrm{Nd}$ value in sample 36 is caused by elevated $\mathrm{Nd}$, which in turn is a result of large apatite crystals in the sample. REE abundances in this sample probably do not

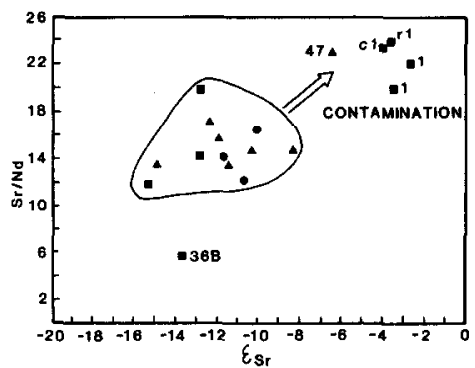

FIG. 7. Sr/Nd versus $\mathrm{\epsilon}_{\mathrm{s} r}$ for lavas from Skien. Sample designations as in Fig. 2. The field encloses typical values; the shift away from this field in samples 47 and 1 , including the core ( $\mathrm{cl}$ ) and rim ( $\mathrm{rl}$ ) of clinopyroxene, is attributed to contamination of these samples by a more radiogenic $\mathrm{Sr}$ reservoir.

represent liquid compositions. $\epsilon_{\mathrm{S} r}$ for this sample is similar to other flows. In fact, two samples from the flow, one analyzed by Jacobsen and one by us, yield quite different abundances of the elements but similar isotopic composition. Therefore, the low $\mathrm{Sr} / \mathrm{Nd}$ for sample 36 is probably simply a function of modal apatite.

The high $\mathrm{Sr} / \mathrm{Nd}$ values for samples 10 and 47, on the other hand, result from overabundance of $\mathrm{Sr}$ compared to other lavas of similar chemistry (Table 2). High $\mathrm{Sr}$ abundances are found in the pyroxenes of sample 1 as well. Samples 1 and 47 also have the most radiogenic Sr. The correlation suggests that these rocks interacted with a reservoir having high $\mathrm{Sr} / \mathrm{Nd}$ and radiogenic Sr. Although the nature of this reservoir cannot be deduced from the data at hand, potential candidates are metasomatic fluid, crust or $\mathrm{Sr}$ radiogenic mantle. A clue to the nature of the contaminant could perhaps be found by a more rigorous examination of the $\mathrm{Rb}$ and $\mathrm{Sr}$ budget in the mineral separates. If we consider for the sake of argument that the radiogenic $\mathrm{Sr}$ of the clinopyroxene core is intrinsic, then the length of time required by intragranular diffusion, approximately $10^{4}$ years, would necessitate that core, rim and melt were in isotopic equilibrium and, thus, that contamination occurred before the final ascent of the magma. (Diffusion rates of $\mathrm{Nd}$ and $\mathrm{Sr}$ in clinopyroxene are $10^{-16} \mathrm{~cm}^{2} / \mathrm{sec}$ at $1000^{\circ} \mathrm{C}$ (SNEERINGER et al., 1984), and using the simple half-distance equation for diffusion, $x=\sqrt{\mathrm{Dt}}$, homogenization of isotopic values over $1 \mathrm{~cm}$ would require approximately $10^{4}$ years.) Our cleaning procedure would almost certainly have removed any carbonate or "caliche" component, such as was documented by ZINDLER and JAGOUTZ (1988). However, whether a more vigorous acidwashing would remove an additional radiogenic component, and whether that would be of pre- or post-ascent parentage, remains to be investigated.

Whatever its nature, the observation that there has been contamination remains valid. Exclusion of these samples shows that the principal isotopic trend exhibited by the sequence was very nearly vertical (Fig. 5).

\section{Nature of the isotopic reservoirs}

Two hypotheses could explain the vertical trend observed in Fig. 5: the first is mixing between a mantle with $\epsilon_{\mathrm{Nd}}$ more positive than the Skien lavas and a crustal component with 
negative $\epsilon_{\mathrm{Nd}}$; the second hypothesis is progressive tapping of two different mantle reservoirs. We prefer the second as the dominant process, chiefly because the magmas with the most primitive $\epsilon_{\mathrm{Nd}}$ are the nephelinites. If isotopic composition is to be attributed to crustal mixing, these would have the greatest proportion of admixture. In fact, since the nephelinites have higher concentrations of $\mathrm{Nd}$ than the alkali basalts, the proportion of crust necessary for resetting the isotopic system would be even greater. However, nephelinite magmas would be most susceptible to obliteration of their special chemical nature during interaction or mixing. Experimental studies have shown that nephelinite magmas are generated under special conditions of high pressure, high $\mathrm{CO}_{2}$ content, and low degrees of melting. Interaction of these magmas with any other chemical reservoir, be it crustal or mantle, would result in loss of the extreme silica undersaturation and a decrease in the abundances of LREE, Th and $\mathrm{Nb}$. The nephelinites from Skien retain these special characteristics, implying that the magmas rose to the surface with minimal interaction. We argue by extension that the flows retain their original isotopic composition. Studies in the Rio Grande Rift (PERRY et al., 1987) and Rhine Graben (WORNER et al., 1986) have also attributed isotopic variability to mantle heterogeneity rather than crust-mantle interactions, and have documented a more chondritic or primitive source for the alkaline rocks and a more depleted one for the basaltic rocks.

Despite the rarity of the "LoNd" isotopic signature in volcanic rocks, there are allied families of rocks with similar isotopic characteristics. These include xenoliths from continental lithosphere and rocks with chemical and tectonic affinities to those at Skien, that is, rocks of continental alkaline nature. Examples are carbonatites from the Fen Complex and the St. Lawrence Rift and alkali basalts and nephelinites from the Colorado Plateau (ALIBERT et al., 1986; BELL and BLENKINSOP, 1987). This type of source, including similarities in $\mathrm{C}, \mathrm{O}$ and $\mathrm{Pb}$, was proposed as common to many carbonatite complexes by NELSON et al. (1988). We should bear in mind that the hypothesis of mixing across a region in Sr-Nd space is only necessary when there is no evidence for a reservoir with the characteristics intrinsic to that region.

We envision that the nephelinites in the Oslo region reflect melting of a source region with an approximately chondritic $\epsilon_{\mathrm{Nd}}$ and negative $\epsilon_{\mathrm{Sr}}$. Progressive melts, still generated in a garnet-bearing source, interacted with (or were derived from) a mantle which imparted to them a more radiogenic $\mathrm{Nd}$ isotopic character. Thus, as the flows changed to less strongly nepheline normative compositions, their isotopic compositions moved in a subvertical manner towards the "mantle array". Finally, tholeiites with a depleted signature ( $\epsilon_{\mathrm{Nd}}$ of +3 to +4 and $\epsilon_{\mathrm{Sr}}$ of -3 to -10 ) became dominant (NEUMANN et al, 1988). These values are not as depleted as MORBtype asthenosphere, which would be characterized by $\epsilon_{\mathrm{Nd}}$ of +7 and $\epsilon_{\mathrm{Sr}}$ values of -23 at $300 \mathrm{Ma}$ ago. They are perhaps similar to PREMA (prevalent mantle of ZINDLER and HART, 1986) for Permo-Carboniferous time.

Nd model ages for the Skien nephelinites range from 600 to $800 \mathrm{Ma}$ for depleted mantle (DM) calculations and 190 to 220 for undepleted reservoir (UR) (Table 2). These model ages, along with the other isotopic data, are consistent with two alternatives for the nature of the nephelinite source. The first is a mantle which was approximately chondritic (or primitive) with respect to Nd isotopes but had undergone at some previous time a decrease in $\mathrm{Rb} / \mathrm{Sr}$ and an increase in $\mathrm{U} / \mathrm{Pb}$. The $\mathrm{t}_{\mathrm{UR}}$ model ages are consistent with this hypothesis if we allow a minor amount of mixing in the nephelinites in order to account for the $80 \mathrm{Ma}$ discrepancy between model and igneous age.

The second possibility is mantle which had undergone depletion of LREE and Rb in the normal way and then subsequently experienced an episode of elemental change characterized by LREE (and $\mathrm{U} / \mathrm{Pb}$ ) enrichment and decrease in $\mathrm{Rb} / \mathrm{Sr}$. These are the kinds of chemical transformations attributed to mantle metasomatism. The $t_{D M}$ are consistent with this hypothesis. It is interesting that the depleted mantle model ages are only slightly older than the Fen Complex. Thus, carbonate fluids invading the mantle and generating the Fen magmatism may have left a localized LREE and Srenriched, Rb-depleted residue which became the Skien source. The $\epsilon_{\mathrm{Nd}}$ of the Fen complex is +4 (ANDERSEN, 1987). Since the Fen Complex is older than Skien, it should lie closer to depleted mantle. $\mathrm{Pb}$ isotopes at Fen are quite radiogenic (ANDERSEN and TAYLOR, 1988), implying a high U/Pb regime during carbonatite genesis, so they are also consistent with this hypothesis. HART et al. (1986) also concluded that metasomatized lithosphere may be a likely candidate for mantle with "LoNd" characteristics.

\section{CONCLUSIONS}

1. A series of flows from the Oslo Rift progress upsection from nephelinites through basanites to alkali basalts. Each of these rock types has its own trace-element and isotopic characteristics: the nephelinites have the greatest enrichments in $\mathrm{Th}, \mathrm{Nb}, \mathrm{U}$ and $\mathrm{Ta}$, and the LREE and $\epsilon_{\mathrm{Nd}}$ values of approximately +1 . The basanites show intermediate enrichments in these trace elements and $\epsilon_{\mathrm{Nd}}$ values of +2 , and the alkali basalts show the lowest enrichment of trace elements and $\epsilon_{\mathrm{Nd}}$ of +4 . $\epsilon_{\mathrm{Sr}}$ for all rocks is approximately -12 , causing the nephelinites to fall on the LoNd array and the other flows to be disposed in a subvertical fashion towards more typical mantle values on a $\epsilon_{\mathrm{Nd}} v s$. $\epsilon_{\mathrm{Sr}}$ diagram.

2. Radiogenic and stable isotope data suggest that the carbonate in calcitic segregations in the nephelinites is magmatic and that it formed by exsolution of $\mathrm{CO}_{2}$ from the silicate melt.

3. Although the magmas may have interacted to some extent with the continental crust through which they ascend, the dominant process was mixing between two mantle reservoirs. The nephelinites represent a source which was approximately chondritic with respect to $\mathrm{Nd}$ isotopic composition but depleted with respect to radiogenic Sr. The alkali basalts represent a source similar to the central Oslo Region tholeiites which followed the magmatism at Skien. We suggest that the small degrees of partial melting during rift initiation allowed sampling of this special reservoir before it was overwhelmed by the volumetrically larger tholeiitic (depleted) reservoir.

4. The nature and location of the mantle reservoirs are poorly constrained. Neither resembles values representative 
of Permian "mid-ocean ridge type" asthenosphere or primitive mantle. The characteristics of the nephelinite source are shared by other continental alkaline provinces, such as the Colorado Plateau and the St. Lawrence Rift. The isotopic character of the 550-Ma-old Fen Alkaline Complex is similar to that of the flows at Skien, indicating that this particular kind of mantle had been strongly coupled to the continent of the Oslo rcgion for at least $250 \mathrm{Ma}$. Further, model age calculations based on depleted mantle are consistent with the hypothesis that the nephelinite source was created by LREE enrichment during Fen magmatism.

Acknowledgements-We thank Euan Mearns, Toril Enger, and Arne Stabel for maintaining the $\mathrm{Sr} / \mathrm{Nd}$ isotope lab at the University of Oslo, A. O. Brunfelt for his help over the years in the collection of the NAA and gamma-ray data, and the staff at the Institute for Energy Research, Kjeller, Norway, for help with the stable isotope and REE analyses. Matthew Thirwall asked a good question at a meeting which caused us to re-examine the nature of metasomatic processes. The manuscript was improved by reviews by S. A. Morse and an anonymous revicwer. E. Anthony was supported by a post-doctoral fellowship from the Royal Norwegian Council for Applied Science and Technology (NTNF) during the course of this study, and she would like to thank the faculty, staff and students at the University of Oslo for a very pleasurable year in Norway. T. V. Segalstad acknowledges support from Grosserer cand. jur. Halvdan Bjørum's legacy for the trace-element analyses, and E.-R. Neumann acknowledges support from the Royal Norwegian Council for Pure Science and Humanities (NAVF), Gaye Evans, through the generosity of the Department of Geology in the National Museum of Wales, provided the drafting.

Editorial handling: G. Faure

\section{REFERENCES}

Alibert C., Michard A. and Albarkede F. (1986) Isotope and trace element geochemistry of Colorado Platcau volcanics. Geochim. Cosmochim. Acta 50, 2735-2750.

ANDERSEN T. (1987) Mantle and crustal components in a carbonatite complex, and the evolution of carbonatite magma: REE and isotopic evidence from the Fen complex, S.E. Norway. Chem. Geol. Isotope 65, 147-166.

ANDERSEN T. and TAYLOR P. N. (1988) Pb isotope geochemistry of the Fen carbonatite complex, S.E. Norway: Age and petrogenetic implications. Geochim. Cosmochim. Acta 52, 209-215.

AOKI K. and KUSHIRO I. (1968) Some clinopyroxenes from ultramafic inclusions in Dreiser Weiher, Eifel. Contrib. Mineral. Petrol. 18, 326-337.

BEDSON P. (1984) Rare earth element distribution between immiscible silicate and carbonate liquids. NERC Progress in Exper. Petrol. (NERC Publ. Series D 25), 12-19.

BELL K. and BLENKINSOP J. (1987) Archean depleted mantle: Evidence from $\mathrm{Nd}$ and $\mathrm{Sr}$ initial isotopic ratios of carbonatites. Geochim. Cosmochim. Acta 51, 291-298.

BOTTINGA Y. (1968) Calculation of fractionation factors for carbon and oxygen exchange in the system calcite-carbon dioxide-water. I. Phys. Chem. 72, 800-808.

BoTTINGA Y. and JAVOY M. (1974) Oxygen isotope geothermometry of igneous and metamorphic rocks. Eos 55, 477.

Brunfelt A. O., RoelandTs I. and STeinNes E. (1974) Determination of rubidium, caesium, barium, and eight rare earth elements in ultramafic rocks by neutron activation analysis. Analyst 99, 277-284.

DEINES P. and Gold D. P. (1973) The isotopic composition of carbonatite and kimberlite carbonates and their bearing on the isotopic composition of deep-seated carbon. Geochim. Cosmochim. Acta 37, 1709-1733.

Deines P., Harris J. W. and GuRney J. J. (1987) Carbon isotopic composition, nitrogen content and inclusion composition of the diamonds from the Roberts Victor kimberlite, South Africa: Evidence for ${ }^{13} \mathrm{C}$ depletion in the mantle. Geochim. Cosmochim. Acta 51, 1227-1243.

Des MARAIS D. J. and Moore J. G. (1984) Carbon and its isotopes in mid-oceanic basaltic glasses. Earth Planet. Sci. Lett. 69, 43-57.

EXLEY R. A. and JONES A. P. (1983) ${ }^{87} \mathrm{Sr} /{ }^{86} \mathrm{Sr}$ in kimberlitic carbonates by ion microprobe: Hydrothermal alteration, crustal contamination, and relation to carbonatite. Contrib. Mineral. Petrol. 83, 288-292.

GERLACH T. M. and ThOMAS D. M. (1986) Carbon and sulphur isotopic composition of Kilauea parental magma. Nature 319, 480483.

GladNEy E. S., Burns C. E. and RoelandTS I. (1983) 1982 compilation of elemental concentrations in eleven United States Geological Survey rock standards. Geostandards Newsletter 7, 3-226.

GREEN D. H. ( 1970) The origin of basaltic and nephelinitic magmas. Trans. Leicester Lit. Phil. Soc. 64, 28-54.

Hart S. R., Gerlach D. C. and White W. M. (1986) A possible new $\mathrm{Sr}-\mathrm{Nd}-\mathrm{Pb}$ mantle array and consequences for mantle mixing. Geochim. Cosmochim. Acta 50, 1551-1557.

Hofmann A. W., Jochum K. P., Seufert M. and White W. M. (1986) $\mathrm{Nb}$ and $\mathrm{Pb}$ in oceanic basalts: New constraints on mantle evolution. Earth Planet. Sci. Lett. 79, 33-45.

Honda M., Reynolds J. H., Roedder E. and EPSTEIN S. (1987) Noble gases in diamonds: Occurrences of solar-like helium and neon. J. Geophys. Res. 92, 12507-12521.

JACOBSEN S. B. (1980) Study of crust and mantle differentiation processes from variations in $\mathrm{Nd}, \mathrm{Sr}$, and $\mathrm{Pb}$ isotopes. $\mathrm{Ph} . \mathrm{D}$. thesis, California Institute of Technology.

JACOBSEN S. B. and WASSERBURG G. J. (1978) Nd and Sr isotopic study of the Permian Oslo Rift. U. S. Geol. Survey Open-file Rept. 78-701, 194-196.

Javoy M., Pineau F. and Iayama I. (1978) Experimental determination of isotopic fractionation between gaseous $\mathrm{CO}_{2}$ and carbon dissolved in tholeiitic magma. Contrib. Mineral. Petrol. 67, 3539.

KIEFFER S. W. (1982) Thermodynamics and lattice vibrations of minerals: 5. Applications to phase equilibria, isotopic fractionation, and high-pressure thermodynamic properties. Rev. Geophys. Space Phys. 20, 827-849.

Le Bas M. J., Le Maitre R. W., Strfick fisfin A. and Zanfttin B. (1986) A chemical classification of volcanic rocks based on the total alkali-silica diagram. J. Petrol. 27, 745-750.

Lucido G., Nuccio P. M., Leake G. and Longinelli A. (1980) Amygdaloidal basalts: Isotopic and petrographic evidence for nondiagenetic crustal source of carbonate inclusions. Tschermaks Mineral. Petrol. Mitt. 27, 113-128.

MASON D. R. (1985) Polybaric crystallization of clinopyroxene in ankaramites of the Barrington Tops Tertiary volcanic field, New South Wales. In Volcanism in Eastern Australia, with Case Histories from New South Wales (eds. F. L. SUTHERLAND, B. J. Franklin and R. E. Waltho), pp. 87-105. Publ. Geol. Soc. Aust., NSW Div. 1.

Matthews A., Goldsmith J. R. and Clayton R. N. (1983) Oxygen isotope fractionations involving pyroxenes: The calibration of mineral-pair geothermometers. Geochim. Cosmochim. Acta 47, 631-644.

Nelson D. R., Chivas A. R., Chappell B. W. and MCCulloch M. T. (1988) Geochemical and isotopic systematics in carbonatites and implications for the evolution of ocean-island sources. Geochim. Cosmochim. Acta 52, 1-17.

NEUMANN E.-R. (1976) Two new refinements for the calculation of structural formulae for pyroxenes and amphiboles. Nor. Geol. Tidsskr. 56, 1-6.

Neumann E.-R. and Ramberg I. B., eds. (1978) Petrology and Geochemistry of Continental Rifts. D. Reidel.

Neumann E.-R., Tilton G. R. and Tuen E. (1988) Sr, Nd, and $\mathrm{Pb}$ isotope geochemistry of the Oslo rift igneous province, southeast Norway. Geochim. Cosmochim. Acta 52, 1997-2007.

PERRY F. V., Baldridge W. S. and DePaOlo D. J. (1987) Role of asthenosphere and lithosphere in the genesis of Late Cenozoic basaltic rocks from the Rio Grande Rift and adjacent regions of the southwestern United States. J. Geophys. Res. 92, 9193-9213. 
RAMBERG I. B. and LARSEN B. T. (1978) Tectonomagmatic evolution. Norges Geol. Unders. 337, 105-124.

SCHAIRER J. F. and Yoder H. S., JR. (1960) The nature of residual liquids from crystallization, with data on the system nephelinediopside-silica. Amer. J. Sci. 258-A, 273-283.

SEGALSTAD T. V. (1975) Cauldron subsidences, ring-structures, and major faults in the Skien district, Norway. Nor. Geol. Tidsskr. 55, 321-333.

SEGALSTAD T. V. ( 1976) Geology of the Skien basalts, southwestern Oslo Region. Cand. real. thesis, University of Oslo, 242p.

Segalstad T. V. (1978) Petrology of the Skien basaltic rocks and the early basaltic $\left(B_{1}\right)$ volcanism of the Permian Oslo Rift. In Petrology and Geochemistry of Continental Rifts (eds. E.-R. NEUMANN and I. B. RAMBERG), pp. 209-216. D. Reidel.

Segalstad T. V. (1979) Petrology of the Skien basaltic rocks, southwestern Oslo Region, Norway. Lithos 12, 221-239.

SEgalstad T. V., JohaNSEN H. and OHMOTO H. (1986) Geochemistry of hydrothermal processes at the Kongsberg silver deposit, southern Norway. Terra Cognita 6, 511 .

SHEPPARD S. M. F. (1982) Stable isotope geochemistry of fluids. Phys. Chem. Earth 13-14, 419-443.

SNEeringer M., HART S. R. and SHIMIZU N. (1984) Strontium and samarium diffusion in diopside. Geochim. Cosmochim. Acta 48, 1589-1608.

SuNDVOLL B. ( 1978) Rb/Sr relationships in the Oslo igneous rocks. In Petrology and Geochemistry of Continental Rifts (eds. E.-R. NEUMANN and I. B. RAMBERG), pp. 181-184. D. Reidel.

WASS S. Y. (1979) Multiple origins of clinopyroxenes in alkali basaltic rocks. Lithos 12, 115-132.

WENDLANDT R. F. and HARRISON W. J. (1979) Rare earth partitioning between immiscible carbonate and silicate liquids and $\mathrm{CO}_{2}$ vapor: Results and implications for the formation of light rare earth-enriched rocks. Contrib. Mineral. Petrol. 69, 409-419.

White W. M. and PatchetT P. J. (1984) Hf-Nd-Sr isotopes and incompatible element abundances in island arcs: Implications for magma origins and crust-mantle evolution. Earth Planet. Sci. Lett. 67, 167-185.

WORNER G., Zindler A., STAUdigel H. and SChMinCKe H.-U. (1986) $\mathrm{Sr}, \mathrm{Nd}$, and $\mathrm{Pb}$ isotope geochemistry of Tertiary and Quaternary alkaline volcanics from West Germany. Earth Planet. Sci. Lett. 79, 107-119.

ZinDler A. and HART S. (1986) Chemical geodynamics. Ann. Rev. Earth Planet. Sci. 14, 493-571.

ZINDLER A. and JAGOUTZ E. (1988) Mantle cryptology. Geochim. Cosmochim. Acta 52, 319-333. 